\title{
Ovotransferrin from Egg White via MAPK Signaling Pathways in RAW 264.7 Macrophages
}

OPEN ACCESS

\section{Received October 15, 2018 \\ Revised November 13, 2018 \\ Accepted November 14, 2018}

*Corresponding author : Hyun-Dong Paik
Department of Food Science and
Biotechnology of Animal Resources, Konkuk
University, Seoul 05029, Korea.
Tel: +82-2-2049-6011
Fax: +82-2-455-8082
E-mail: hdpaik@konkuk.ac.kr
*ORCID
Jae Hoon Lee
0000-0002-7440-6842
Dong Uk Ahn
0000-0001-9523-7630
Hyun-Dong Paik
0000-0001-9891-7703

\author{
Jae Hoon Lee ${ }^{1}$, Dong Uk Ahn², and Hyun-Dong Paik ${ }^{1, *}$ \\ ${ }^{1}$ Department of Food Science and Biotechnology of Animal Resources, Konkuk \\ University, Seoul 05029, Korea \\ ${ }^{2}$ Department of Animal Science, lowa State University, Ames, Iowa 50011, USA
}

\begin{abstract}
Ovotransferrin (OTF) is a well-known protein of the transferrin family with strong iron chelating activity, resulting in its antimicrobial activity. Furthermore, OTF is known to have antioxidant, anticancer, and antihypertensive activities. However, there have been few studies about the immune-enhancing activity of OTF. In current study, we investigated the immune-enhancing activity of OTF using the murine macrophage cells in vitro. The effect of OTF on production of pro-inflammatory mediators and cytokines were determined using Griess assay and quantitative real-time PCR. Using Neutral Red uptake assay, we confirmed the effect of OTF on phagocytic activity of macrophages. Ovotransferrin significantly increased the production of nitric oxide (NO) and secretion of inducible nitric oxide synthase (iNOS) mRNA with no cytotoxic activity. Ovotransferrin (2 $\mathrm{mg} / \mathrm{mL}$ ) stimulated NO production up to $31.9 \pm 3.5 \mu \mathrm{M}$. Ovotransferrin significantly increased the mRNA expression levels of pro-inflammatory cytokines which are tumor necrosis factor- $\alpha$ (TNF- $\alpha)$, Interleukin-1 $\beta$ (IL-1 $\beta)$, and IL-6: OTF $(2 \mathrm{mg} / \mathrm{mL})$ treatment increased the secretion of mRNA for TNF- $\alpha$, IL-1 $\beta$, and IL- 6 by 22.20-, 37.91-, and 6.17fold of the negative control, respectively. The phagocytic activity of macrophages was also increased by OTF treatment significantly compared with negative control. Also, OTF treatment increased phosphorylation level of MAPK signaling pathways. These results indicated that OTF has immune-enhancing activity by activating RAW 264.7 macrophages via MAPK pathways.
\end{abstract}

Keywords egg white protein, ovotransferrin, immune-enhancing activity, MAPK pathway, RAW 264.7 macrophage

\section{Introduction}

Egg white ovotransferrin (OTF) is a well-characterized transferrin protein with strong iron-binding properties and is the second major protein in egg white and it account for $12 \%-13 \%$ of protein content ( $\mathrm{Wu}$ and Acero-Lopez, 2012). OTF is consisted of 686 amino acids and its molecular weight is known as $78 \mathrm{kDa}$. OTF has two lobes containing each a single iron-binding site (N-lobe: 1-329 amino acids; C-

(C) Korean Society for Food Science of Animal Resources. This is an open access article distributed under the terms of the Creative Commons Attribution Non-Commercial License (http://creativecommons.org/licences/by-nc/3.0) which permits unrestricted non-commercial use, distribution, and reproduction in any medium, provided the original work is properly cited. 
lobe: 330-686 amino acids). This is the reason that OTF have a strong iron-binding activity. And this activity gave an antimicrobial activity to OTF by removing iron ion from microbes (Abdallah and Chahine, 1999). Furthermore, OTF has been reported to have antifungal, antioxidant, antiviral, and anticancer activity (Giansanti et al., 2002; Ibrahim et al., 2007; Moon et al., 2013; Valenti et al., 1985). Although recent studies have revealed diverse functional activities of OTF, little is known about its immune-enhancing activity.

The immunomodulators used in enhancing the host defense system have being highlighted in recent years (Zhao et al., 2014). The modulation of immune response is especially important for people who have impaired immune responses such as the elderly and cancer patients, because it plays a crucial role in diseases prevention (Salvioli et al., 2006). Accordingly, immunomodulation induced by active substances have been the focus of many studies (Castro et al., 2008; Hong et al., 2017; Shen et al., 2017). They found new active substances from natural materials which are herb, egg, and grape etc. In these natural materials, polysaccharides, proteins, and resveratrol are separated, and they are reported to have immunomodulating activity.

Macrophages play an important role in both the innate and the adaptive immune system. They exist in the body widely. When the body is attacked by pathological stimuli or is injured, macrophages defend the body through the production of proinflammatory chemokines and cytokines which are nitric oxide (NO), interleukin family (IL-1 $\beta$, IL-6, and IL-12), interferon$\gamma($ IFN- $\gamma$ ), and tumor necrosis factor- $\alpha$ (TNF- $\alpha$ ) (Wang et al., 2017; Yu et al., 2017). Macrophage activation is an essential process for defending the body against pathogens. When macrophages are activated, they initiate and propagate defensive reactions such as phagocytosis and production of pro-inflammatory mediators (Yu et al., 2017). Macrophage activation is associated with the major signaling pathways such as mitogen activated protein kinase (MAPK) which include p38 MAPK, extracellular signal regulated kinase (ERK), c-Jun N-terminal kinase (JNK) (Han et al., 2009). Therefore, many researchers have been studying new substances with immunomodulatory and immunostimulatory activities that activate macrophages via MAPK pathway (Hong et al., 2017; Li et al., 2017; Seo et al., 2015).

In the current study, the immune-enhancing activity of OTF obtained from hen egg white was investigated by measuring the pro-inflammatory chemokine and cytokine levels in RAW 264.7 macrophages. Furthermore, we assessed whether activation of macrophages induced by OTF is associated with MAPK pathways.

\section{Materials and Methods}

\section{Materials}

The iron-free OTF was prepared using the method of Abeyrathne et al. (2013). Dulbeco's modified Eagle's medium (DMEM), fetal bovine serum (FBS), and penicillin-streptomycin were purchased from HyClone Laboratories, Inc. (Logan, MI, USA). N-(1-naphthyl)-ethylenediamine, sulfanilamide, thiazolyl blue tetrazolium bromide (MTT), lipopolysaccharides (LPS), and dimethyl sulfoxide (DMSO) were purchased from Sigma-Aldrich Co. (St. Louis, MO, USA). Antibodies against phospho-p38 (p-p38), total p38 (t-p38), phospho-ERK (p-ERK), total ERK (t-ERK), phospho-JNK (p-JNK), and total JNK (tJNK) were obtained from Santa Cruz Biotechnology (Dallas, TX, USA). Goat anti-mouse IgG-HRP and materials for western blot were obtained from Bio-Rad (Hercules, CA, USA).

\section{Cell culture}

RAW 264.7 macrophages were obrained from Korean Cell Line Bank (Seoul, Korea). Macrophages were cultured in DMEM medium supplemented with $10 \%$ FBS, penicillin-streptomycin $(100 \mathrm{U} / \mathrm{mL}$ and $100 \mu \mathrm{g} / \mathrm{mL})$ at $37^{\circ} \mathrm{C}$ in an incubator 
containing 5\% $\mathrm{CO}_{2}$ (MCO-18AIC, SANYO, Osaka, Japan). The culture medium was replaced every 2-3 days.

\section{3-(4.5-dimethylthiazol-2-yl)-2,5-diphenyl tetrazolium bromide (MTT) assay}

Cell viability of macrophages against OTF was measured using the MTT assay with slight modifications (Lee et al., 2017). RAW 264.7 macrophages $\left(2 \times 10^{5}\right.$ cells/well) were added to a 96 -well plate and cultured at $37^{\circ} \mathrm{C}$ for $4 \mathrm{~h}$. Various concentration of OTF $(0-2 \mathrm{mg} / \mathrm{mL})$ were then added to each cell suspension and cultured for $24 \mathrm{~h}$. After then, MTT $(2.5 \mathrm{mg} / \mathrm{mL})$ solution dissolved in PBS was added to each well and the plate was incubated at $37^{\circ} \mathrm{C}$ for an additional $4 \mathrm{~h}$. The supernatant was then removed from each well and DMSO was added to dissolve the formazan crystals. The absorbance of each solution was then measured using a microplate reader (Model 680, Bio-Rad, Hercules, CA, USA) at $570 \mathrm{~nm}$.

\section{Griess assay}

The effects of OTF on NO levels of macrophages were measured using the Griess assay (Chen et al., 2014). RAW 264.7 macrophages $\left(2 \times 10^{5}\right.$ cells/well) were added to a 96 -well plate and cultured at $37^{\circ} \mathrm{C}$ for $4 \mathrm{~h}$. Various concentration of OTF $(0-$ $2 \mathrm{mg} / \mathrm{mL}$ ) and LPS (10 ng/mL) were then added to each cell suspension and cultured for $24 \mathrm{~h}$. Lipopolysaccharides was used as a positive control. Griess reagent (mixed with $1 \%$ sulfanilamide dissolved in 5\% phosphoric acid and $0.1 \% \mathrm{~N}-(1-$ naphthyl)-ethylenediamine dihydrochloride dissolved in distilled water) were mixed with each well supernatant. Under aerobic conditions, NO is rapidly converted into nitrite, which then produces the azo dye when mixed with Griess reagent. The absorbance was measured using a microplate reader at $540 \mathrm{~nm}$ and NO concentration was calculated using standard solutions of sodium nitrate dissolved in DMEM medium.

\section{Quantitative real-time PCR (qRT-PCR) assay}

The effects of OTF on expression levels of cytokine were measured using quantitative real-time PCR (qRT-PCR). RAW 264.7 macrophages $\left(1 \times 10^{6}\right.$ cells $/$ well $)$ were added to a 6 -well plate and cultured at $37^{\circ} \mathrm{C}$ for $24 \mathrm{~h}$. Various concentration of OTF $(0-2 \mathrm{mg} / \mathrm{mL})$ and LPS $(10 \mathrm{ng} / \mathrm{mL})$ were then added to each cell suspension and cultured for another $24 \mathrm{~h}$. RNeasy Mini Kit (Qiagen, Milan, Italy) was used for isolating total RNA from macrophages according to the manufacturer's instructions and the RevertAid First strand cDNA synthesis Kit (Thermo Fisher Scientific, Carlsbad, CA, USA) was used for synthesis cDNA. The cytokine primer sequences are shown in Table 1 and the SYBR green reagent (PhileKorea, Daejeon, Korea) was used. The cDNA and primer mixture were pre-heated at $95^{\circ} \mathrm{C}$ for $2 \mathrm{~min}$, followed by PCR for 40 cycles, using a denaturing

Table 1. Primer sequences used in quantitative real-time PCR

\begin{tabular}{|c|c|c|}
\hline Gene & Description & Primer sequence \\
\hline iNOS & Inducible nitric oxide synthase & $\begin{array}{l}\text { Forward: 5'-cccttccgaagtttctggcagcagc-3' } \\
\text { Reverse: } 5^{\prime} \text {-ggctgtcagagcctcgtggctttgg-3' }\end{array}$ \\
\hline TNF- $\alpha$ & Tumor necrosis factor- $\alpha$ & $\begin{array}{l}\text { Forward: 5'-ttgacctcagcgetgagttg-3' } \\
\text { Reverse: 5'-cctgtagcccacgtcgtagc-3' }\end{array}$ \\
\hline IL-1 $\beta$ & Interleukin- $1 \beta$ & $\begin{array}{l}\text { Forward: 5'-caggatgaggacatgagcacc-3' } \\
\text { Reverse: 5'-ctctgcagactcaaactccac-3' }\end{array}$ \\
\hline IL-6 & Interleukin-6 & $\begin{array}{l}\text { Forward: 5'-gtactccagaagaccagagg-3' } \\
\text { Reverse: 5'-tgctggtgacaaccacggec-3' }\end{array}$ \\
\hline$\beta$-actin & & $\begin{array}{l}\text { Forward: 5'-gtgggccgccctaggcaccag-3' } \\
\text { Reverse: 5'-ggaggaagaggatgcggcagt-3' }\end{array}$ \\
\hline
\end{tabular}


temperature $95^{\circ} \mathrm{C}$ for $5 \mathrm{~s}$, and annealing/extension temperature $65^{\circ} \mathrm{C}$ for $30 \mathrm{~s}$. The $\Delta \Delta \mathrm{Ct}$ method was used for analyzing qRTPCR results and melting curve analysis was used for assessing the purity of PCR products.

\section{Neutral red uptake assay}

The effects of OTF on phagocytic activity of RAW 264.7 macrophages were measured using neutral red uptake assay (Wang et al., 2016). RAW 264.7 macrophages $\left(2 \times 10^{5}\right.$ cells/well) were added to a 96 -well plate and cultured at $37^{\circ} \mathrm{C}$ for $4 \mathrm{~h}$. Various concentration of OTF $(0-2 \mathrm{mg} / \mathrm{mL})$ and LPS $(10 \mathrm{ng} / \mathrm{mL})$ were then added to each cell suspension and cultured for 24 h. After incubation, the supernatant was removed and $100 \mu \mathrm{L}$ of $0.075 \%$ neutral red solution was added to the each well and incubated for additional $30 \mathrm{~min}$. After washing three times, lysis buffer [100 $\mu \mathrm{L}, 0.01 \%$ glacial acetic acid: ethanol $=1: 1$, $(\mathrm{v} / \mathrm{v})]$ was added. The absorbance was measured using a microplate reader at $540 \mathrm{~nm}$.

\section{Western blot analysis}

For western blot analysis, RAW 264.7 macrophages $\left(2.5 \times 10^{6}\right.$ cells $/$ well $)$ were added to a 6 -well plate and cultured at $37^{\circ} \mathrm{C}$ for $24 \mathrm{~h}$ and then treated with either OTF $(0-2 \mathrm{mg} / \mathrm{mL})$ or LPS $(10 \mathrm{ng} / \mathrm{mL})$ for $30 \mathrm{~min}$. Total protein was extracted using RIPA buffer (Thermo Fisher Scientific, Waltham, MA, USA) supplemented with protease and phosphatase inhibitor. Protein concentrations were determined according to the Lowry method. Thirty microgram of total protein was separated on a $12 \%$ SDS-PAGE gel and subsequently transferred to PVDF membranes. The membranes were blocked with $5 \%$ skim milk dissolved in TBST (Tris-buffered saline with 1\% Tween-20) for $1 \mathrm{~h}$ and then incubated with primary antibody (p-p38, t-p38, p-ERK, t-ERK, p-JNK, and t-JNK antibodies) overnight at $4^{\circ} \mathrm{C}$. After washing in TBST for $45 \mathrm{~min}$ ( 3 times $\left.\times 15 \mathrm{~min}\right)$, the membranes were incubated with secondary antibodies at room temperature for $2 \mathrm{~h}$. After washing in TBST for 45 min (3 times $\times 15 \mathrm{~min}$ ), using the chemiluminescence western blot detection system the protein bands were detected.

\section{Statistical analysis}

All the data are present as the mean with standard deviation. The experiments were performed in triplicates and the assays were repeated three times. Statistical significance for the difference between groups was using Student's $t$-test. SPSS software version 18 (SPSS Inc., Chicago, IL, USA) was used to perform all statistical analysis.

\section{Results and Discussion}

\section{Ovotransferrin elevate NO production and iNOS secretion in RAW 264.7 macrophages}

Cell viability of RAW 264.7 macrophages with OTF treatment was measured using the MTT assay. All concentrations of OTF (0-2 mg/mL) did not cause any cytotoxicity to RAW 264.7 macrophages (Fig. 1). To assess whether OTF affected the production of NO and iNOS expression, we performed Griess assay and qRT-PCR analysis. Fig. 2A shows the amount of NO production in RAW 264.7 macrophages produced by OTF. Nitric oxide concentration increased dose-dependently increased with OTF treatment ( $\mathrm{p}<0.001$ for $0.5-2 \mathrm{mg} / \mathrm{mL}$, or $\mathrm{p}<0.01$ for $0.25 \mathrm{mg} / \mathrm{mL}$ ). At $2 \mathrm{mg} / \mathrm{mL}$ concentration, OTF increased NO concentration to $31.9 \pm 3.5 \mu \mathrm{M}$, whereas LPS only increased NO concentration to $27.5 \pm 3.3 \mu \mathrm{M}$. Nitric oxide is widely involved in physiological processes such as modulation of vasodilation, neurogenesis and wound healing (Mayer and Hemmens, 1997; Rizk et al., 2004). Furthermore, NO synthesis is an important part of the inflammatory response. Because NO can inactivate mitochondrial respiratory chain enzymes, resulting in cell death in the pathogens (e.g., virus, bacteria, and tumor cells) 


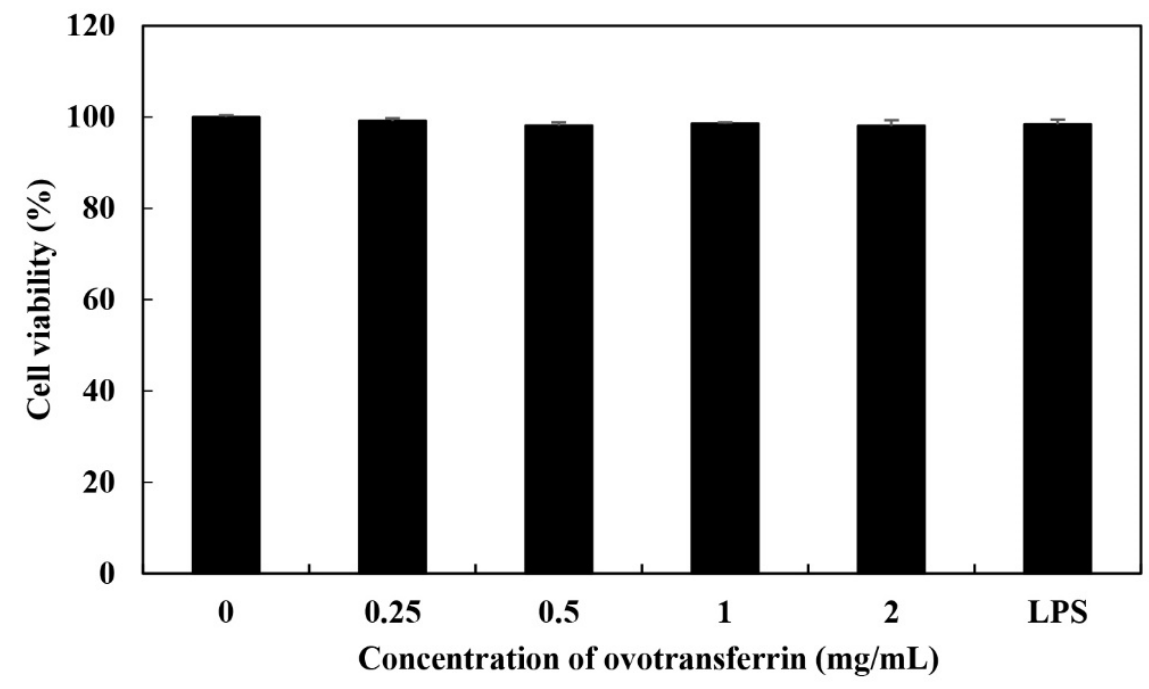

Fig. 1. Effects of ovotransferrin on the viability of RAW 264.7 macrophages. Values are expressed as the mean \pm standard deviation of three replications. LPS: treated group with $10 \mathrm{ng} / \mathrm{mL}$ of LPS. Cell viability $(\%)=$ absorbance of the sample/absorbance of the control $\times 100$.
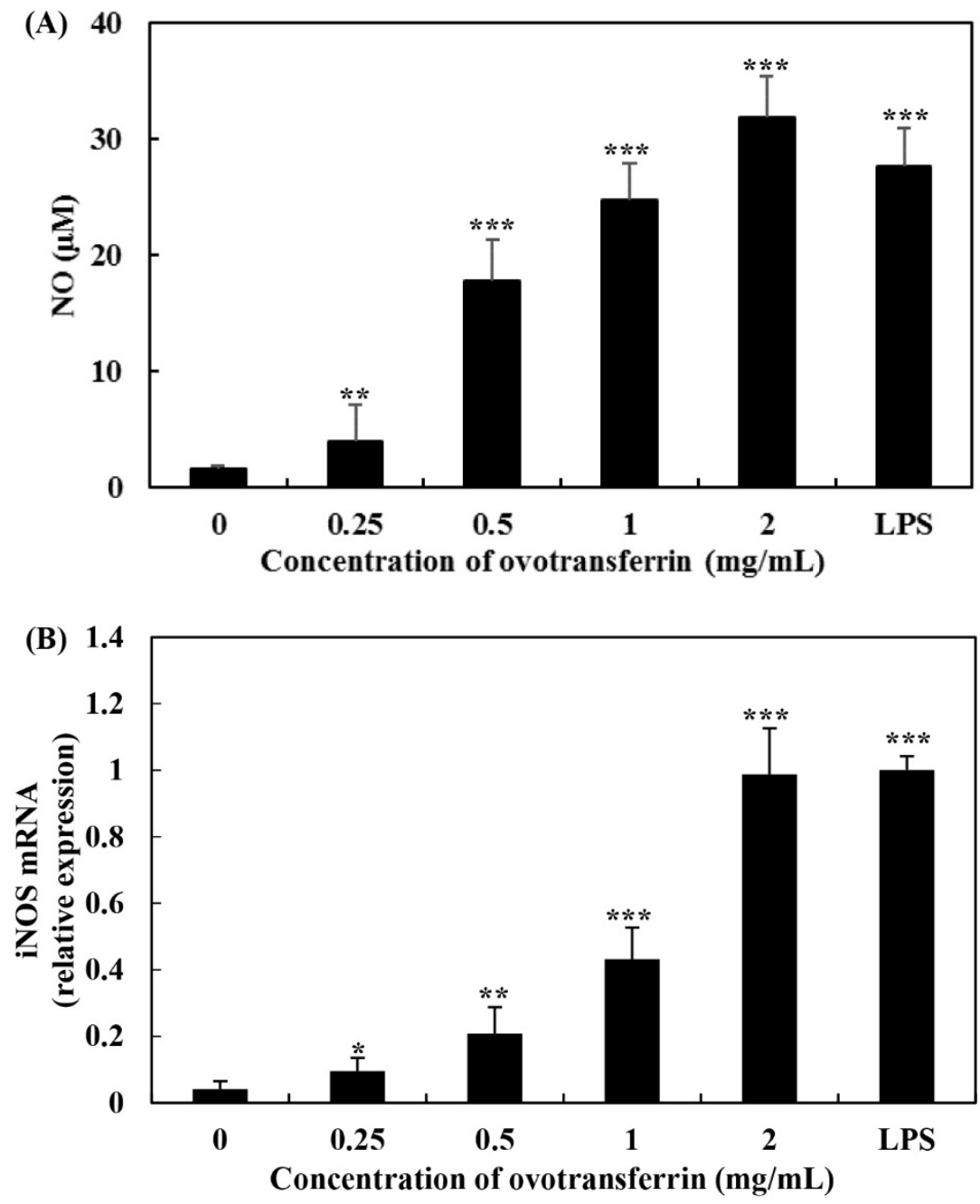

Fig. 2. Effects of ovotransferrin on the production of nitric oxide (NO) (A) and the secretion of inducible nitric oxide synthese (iNOS) mRNA (B) in RAW 264.7 macrophages. Values are expressed as the mean \pm standard deviation of three replications. ${ }^{*},{ }^{* *},{ }^{* * *}$ mean statistical difference for $p<0.05,0.01,0.001$ (Student's $t$-test) compared with $0 \mathrm{mg} / \mathrm{mL}$ treatment group. LPS: treated group with $10 \mathrm{ng} / \mathrm{mL}$ of LPS. 
(MacMicking et al., 1997). In living organisms, NO is synthesized by nitric oxide synthases (NOS) through the oxidative deamination of L-arginine. Nitric oxide synthases have three isoforms which are neuronal NOS, endothelial NOS, and inducible NOS (iNOS). Among the three isoforms, iNOS expression is induced by inflammatory conditions after cell stimulation by microbial or immunological stimuli (Lind et al., 2017). Therefore, we confirmed whether OTF stimulates expression of iNOS.

The effects of OTF on the expression of iNOS are shown in Fig. 2B. OTF $(2 \mathrm{mg} / \mathrm{mL})$ increased expression levels of iNOS by 24.0 -fold $(\mathrm{p}<0.001)$ compared with negative control $(0 \mathrm{mg} / \mathrm{mL}$ OTF treatment $)$. OTF significantly increased expression levels ( $\mathrm{p}<0.001$ for $1 \mathrm{mg} / \mathrm{mL}$, or $\mathrm{p}<0.01$ for $0.25,0.5 \mathrm{mg} / \mathrm{mL}$ ) in a dose-dependent manner, suggesting that the increase of NO production was induced by stimulating the expression of iNOS by OTF treatment. Additionally, representative micrographs of RAW 264.7 macrophages showed some morphological changes between negative control and OTF treated groups (Fig. 3). After treated with OTF and LPS, RAW 264.7 macrophages were activated, and the single cell size became bigger and some branches were added in cells (white arrows in Fig. 3). The concentration of OTF was increased, the changes were more dramatically.

Many studies reported that increased NO via enhanced iNOS expression activates macrophages and improves immuneenhancing activity (Ha et al., 2013; Hong et al., 2017; Li et al., 2017). Li et al. (2017) and Hong et al. (2017) reported that extracted materials from Radix astragali and Cervus nippon mantchuricus have immune-enhancing activity. These extracted materials increased the iNOS mRNA expression and NO production in RAW 264.7 macrophages without causing cytotoxicity. $\mathrm{Ha}$ et al. (2013) found an immunomodulatory activity of Maillard-type lysozyme (conjugated with galactomannan). Specifically, it significantly increased NO expression and affected production of inflammatory cytokines.

\section{Ovotransferrin elevate pro-inflammatory cytokines expression in RAW 264.7 macrophages}

Quantitative real-time PCR analysis was used for assessing the effects of OTF on the expression of pro-inflammatory cytokines (Fig. 4). Compared with the negative control ( $0 \mathrm{mg} / \mathrm{mL}$ OTF treatment), $2 \mathrm{mg} / \mathrm{mL}$ OTF increased levels of TNF- $\alpha$ expression by 22.2 -fold $(\mathrm{p}<0.001)$ (Fig. 4A), similar to LPS $(10 \mathrm{ng} / \mathrm{mL}$, positive control), which increased TNF- $\alpha$ expression by 22.1-fold. Ovotransferrin increased TNF- $\alpha$ expression in a dose-dependent manner (1.6-, 4.8-, and 12.1-fold increase with $0.25,0.5$, and $1 \mathrm{mg} / \mathrm{mL}$ OTF treatment, respectively). Interleukin- $1 \beta$ and IL-6 expression levels also increased with OTF
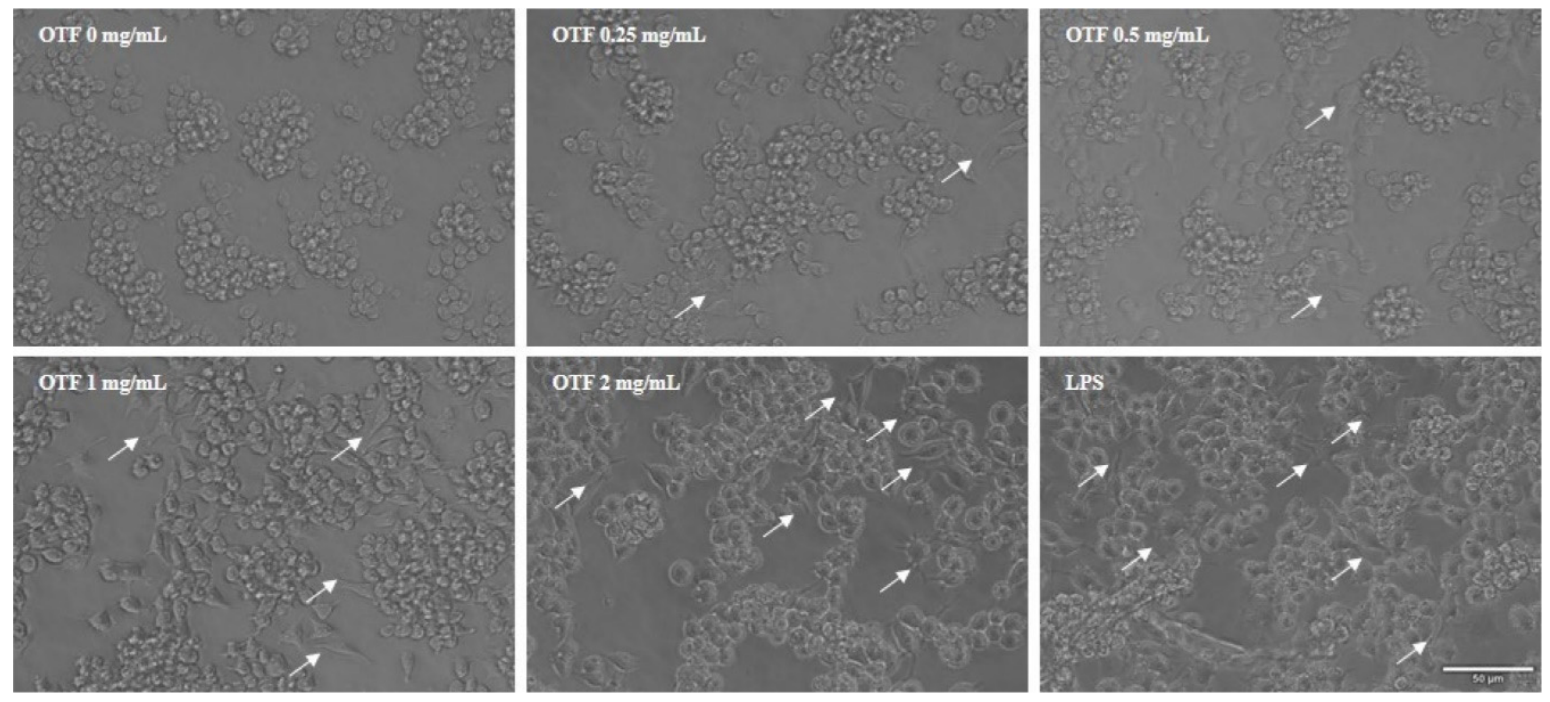

Fig. 3. Effects of ovotransferrin on the morphological changes of RAW 264.7 macrophages. LPS: treated group with $10 \mathrm{ng} / \mathrm{mL}$ of LPS. 


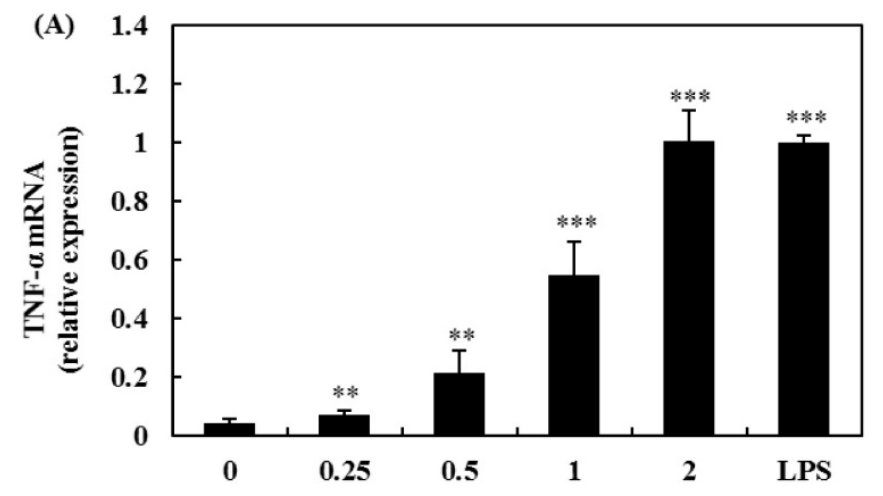

Concentration of ovotransferrin $(\mathrm{mg} / \mathrm{mL})$

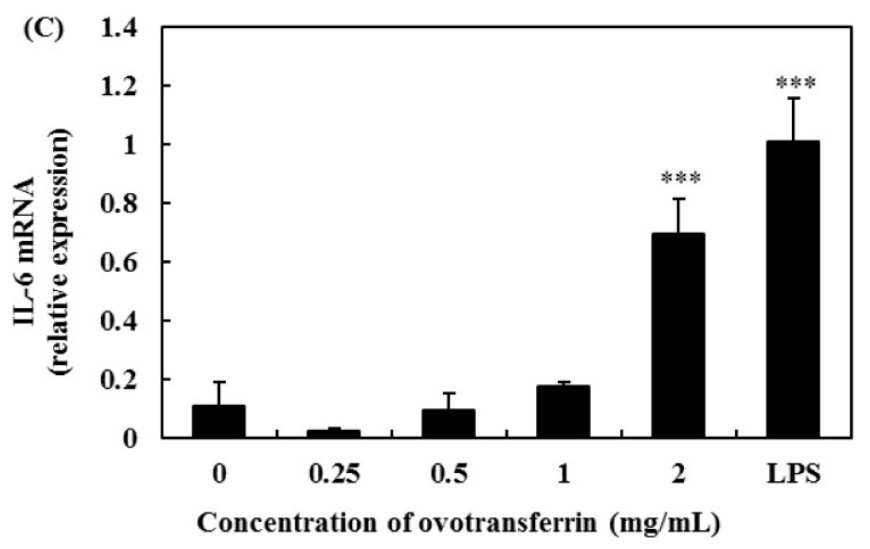

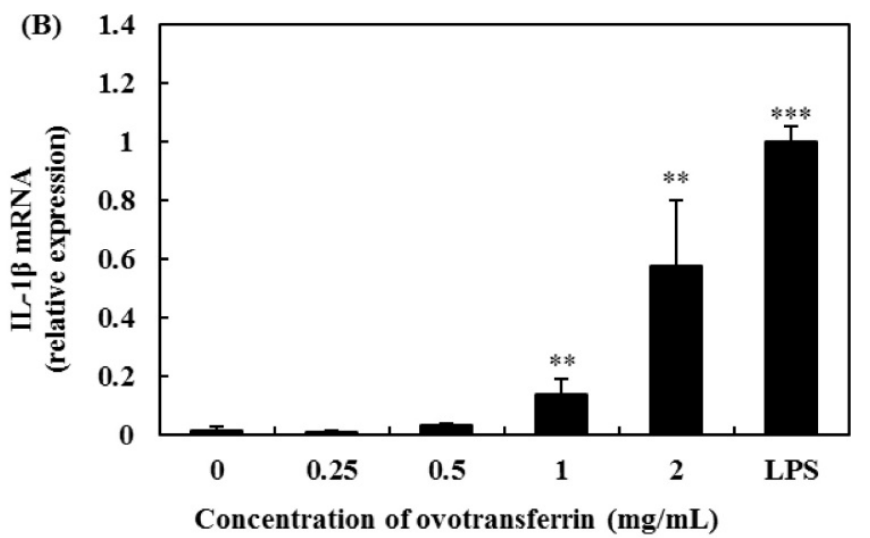

Concentration of ovotransferrin $(\mathrm{mg} / \mathrm{mL})$

Fig. 4. Effects of ovotransferrin on the expression of pro-inflammatory cytokines TNF- $\alpha$ (A), IL-1 $\beta$ (B), and IL-6 (C) in RAW 264.7 macrophages. Values are expressed as the mean \pm standard deviation of three replications. ${ }^{* *},{ }^{* * *}$ mean statistical difference for $p<0.01$, 0.001 (Student's $t$-test) compared with $0 \mathrm{mg} / \mathrm{mL}$ treatment group. LPS: treated group with $10 \mathrm{ng} / \mathrm{mL}$ of LPS.

treatment (Fig. 4B, 4C). OTF (from $1 \mathrm{mg} / \mathrm{mL}$ ) significantly increased IL-1 $\beta$ expression level $(\mathrm{p}<0.01$ ). Interleukin-6 expression required a higher dose of $2 \mathrm{mg} / \mathrm{mL}$ OTF for a significant increase $(\mathrm{p}<0.001)$.

Several bioactive compounds have been reported to be involved in stimulating immune activity, resulting in an increase in secretion of pro-inflammatory cytokines (Hong et al., 2017; Li et al., 2016; Li et al., 2017; Ren et al., 2014; Wang et al., 2013). Tumor necrosis factor- $\alpha$ is the first cytokine which is appeared in the circulation after stimulation of macrophages and it plays an important role in the immune system and induces tumor cell apoptosis (Schooltink and Rose-John, 2002). Furthermore, TNF- $\alpha$ can stimulate the expression of IL-1 $\beta$ and IL-6 (Ahmad et al., 2018; Thieringer et al., 2000). Wang et al. (2013) found that Gelidium amansii gel extracts have immune-enhancing activity by causing an increase in NO and proinflammatory cytokines expression. And these pro-inflammatory cytokines (IL-1 $\beta$ and IL-6) are known to play key roles in inflammatory process. Hong et al. (2017) reported that Cervus nippon mantchuricus extract upregulated the IL-6 and TNF- $\alpha$ mRNA levels in a dose-dependent manner.

\section{Ovotransferrin increase the phagocytic activity of RAW 264.7 macrophages}

Phagocytic activity of macrophages is the characteristic feature. It is the important part in the immune system, and it is the first step of macrophages in the response to pathogens (Cheng et al., 2008). Using the Neutral Red uptake assay, the effects of OTF on phagocytic activity was determined. Upon treating with OTF, phagocytic activity of macrophages was increased (Fig. 5). Compared with negative control $(0 \mathrm{mg} / \mathrm{mL}$ OTF treatment), all OTF treatment group significantly increased phagocytic 


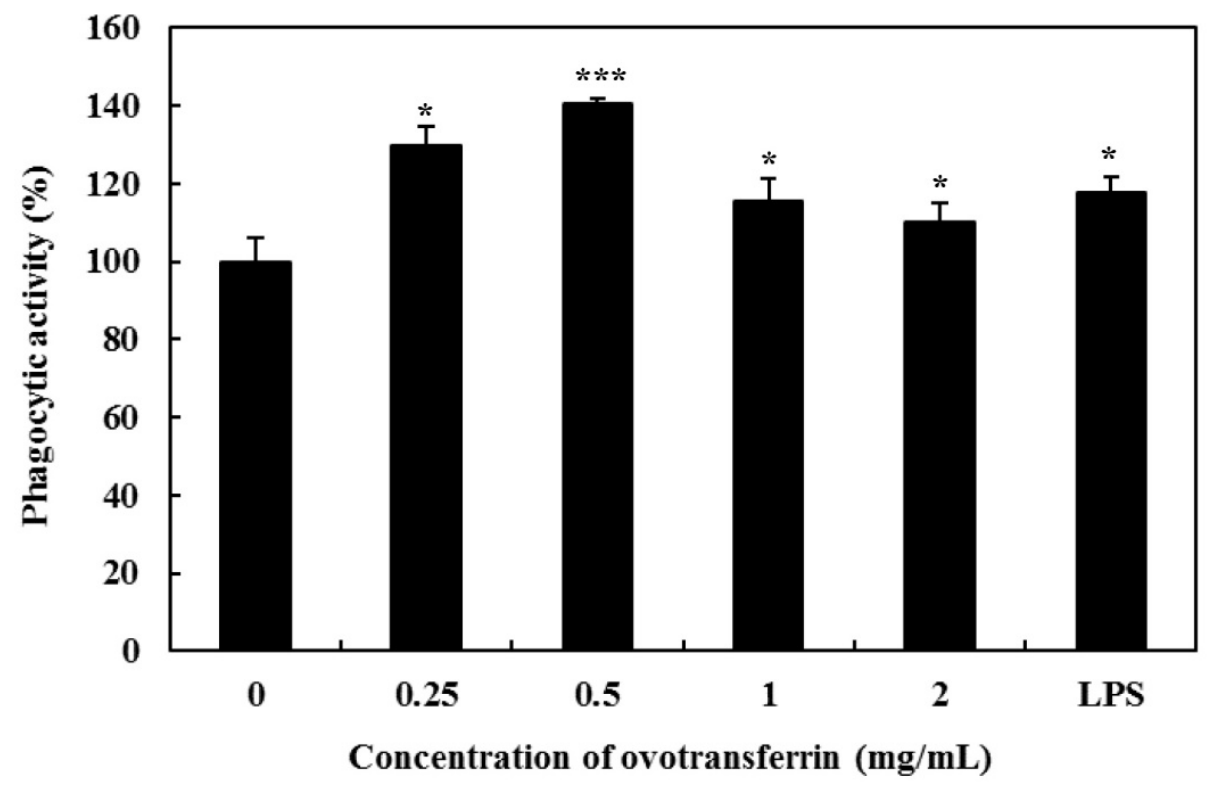

Fig. 5. Effects of ovotransferrin on the phagocytic activity of RAW $\mathbf{2 6 4 . 7}$ macrophages. Values are expressed as the mean \pm standard deviation of three replications. ${ }^{*},{ }^{* *},{ }^{* * *}$ mean statistical difference for $\mathrm{p}<0.05,0.01,0.001$ (Student's $t$-test) compared with $0 \mathrm{mg} / \mathrm{mL}$ treatment group. LPS: treated group with $10 \mathrm{ng} / \mathrm{mL}$ of LPS. Phagocytic activity (\%) = absorbance of the sample/absorbance of the control $\times 100$.

activity ( $\mathrm{p}<0.05$ for $2,1 \mathrm{mg} / \mathrm{mL}$, or $\mathrm{p}<0.001$ for $0.5 \mathrm{mg} / \mathrm{mL}$, or $\mathrm{p}<0.01$ for $0.25 \mathrm{mg} / \mathrm{mL}$ ). Phagocytic activity of macrophages is closely related to the elimination of specific pathogens, tumor cells, and damaged cells (Cameron and Churchill, 1980; Yamamura and Azuma, 1983). Therefore, enhanced phagocytic activity of macrophages by OTF will help boosting the immune function.

\section{Ovotransferrin activate MAPK signaling pathways of RAW 264.7 macrophages}

To determine the mechanism by which OTF activates pro-inflammatory cytokines and upregulates NO production, we assessed signaling pathway activation associated with MAPK (p38, ERK, and JNK). Dauphinee and Karsan (2006) reported that LPS treatment in endothelial cells induced the activation of all three MAPK pathways. Upon treating RAW 264.7 macrophages with OTF, we found that all three MAPK (p38, ERK, JNK pathway) were phosphorylated (Fig. 6). From a concentration of $0.25 \mathrm{mg} / \mathrm{mL}$, OTF induced p38 phosphorylation. Furthermore, phosphorylation of ERK and JNK were induced from a concentration of $0.5 \mathrm{mg} / \mathrm{mL}$. Ovotransferrin induced phosphorylation of all three MAPK in a dose-dependent manner.

Mitogen activated protein kinase pathways are well known to have a crucial role in the innate immune response and adaptive immunity (Dong et al., 2002; Rincon et al., 2000). When MAPK pathways are activated, genes involved in the immune response are expressed by activating several transcription factors, such as NF-кB (Ninomiya-Tsuji et al., 1999). Active NF- $\kappa \mathrm{B}$ then regulates the expression of iNOS and pro-inflammatory cytokines. Many studies about immunemodulating materials reported that they activate macrophages through MAPK pathways (Ha et al., 2013; Hong et al., 2017; Jeong et al., 2015; Seo et al., 2015). These materials induced phosphorylation of all three MAPK in a dose-dependent manner. Ha et al. (2013) found that lysozyme conjugated with galactomannan had immune-enhancing effects by inducing the phosphorylation of JNK. Hong et al. (2017) showed that NGE (extracts from Cervus nippon mantchuricus) activated RAW 


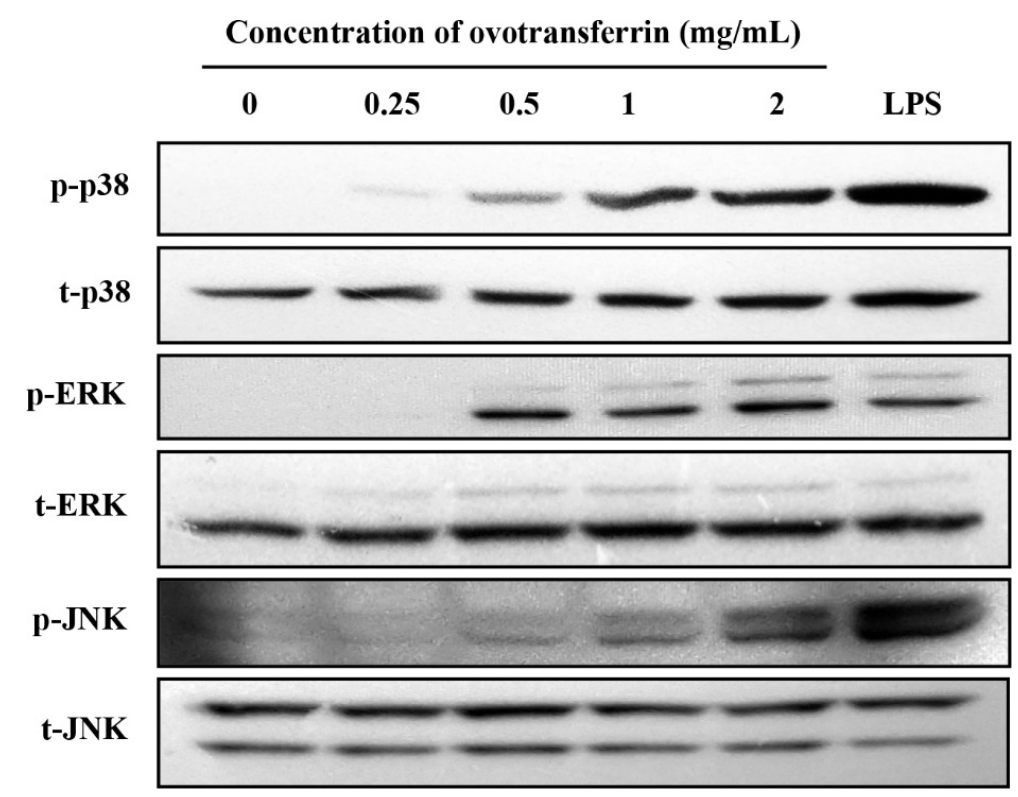

Fig. 6. Effects of ovotransferrin on the activation of MAPK (p38, ERK, and JNK) in RAW 264.7 macrophages. LPS, treated group with 10 $\mathrm{ng} / \mathrm{mL}$ of LPS.

264.7 macrophages, and that MAPK were phosphorylated upon treatment with NGE. They concluded that phosphorylation of MAPK elevates NO production and stimulates expression of iNOS and COX-2.

\section{Conclusion}

In the present study, we confirmed the immune-enhancing activity of OTF from egg white protein in vitro. OTF stimulated the production of NO in RAW 264.7 macrophages and expression of iNOS and pro-inflammatory cytokines such as TNF- $\alpha$, IL-1 $\beta$, and IL-6. We also found that all three MAPK pathways were associated with macrophage activation. These results indicate that OTF has immune-enhancing activity by activating macrophages. Therefore, OTF should be considered as a potential immune-enhancing agent that can be used in the food or pharmaceutical industry. However, further in vivo study is needed to ensure their benefits before being used for human.

\section{Conflicts of Interest}

The authors declare no potential conflict of interest.

\section{Acknowledgments}

This work was supported by Korea Institute of Planning and Evaluation for Technology in Food, Agriculture and Forestry (IPET) through High Value-added Food Technology Development Program, funded by Ministry of Agriculture, Food and Rural Affairs (MAFRA)(118037-3).

\section{References}

Abdallah FB, Chahine, JMEH. 1999. Transferrins, the mechanism of iron release by ovotransferrin. Eur J Biochem 263:912- 
920.

Abeyrathne ED, Lee HY, Ham JS, Ahn DU. 2013. Separation of ovotransferrin from chicken egg white without using organic solvents. Poult Sci 92:1091-1097.

Ahmad W, Jantan I, Kumolosasi E, Haque MA, Bukhari SNA. 2018. Immunomodulatory effects of Tinospora crispa extract and its major compounds on the immune functions of RAW 264.7 macrophages. Int Immunopharmacol 60:141-151.

Cameron DJ, Churchill WH. 1980. Cytotoxicity of human macrophages for tumor cells: Enhancement by bacterial lipopolysaccharides (LPS). J Immunol 124:708-712.

Castro R, Lamas J, Morais P, Sanmartin ML, Orallo F, Leiro J. 2008. Resveratrol modulates innate and inflammatory responses in fish leucocytes. Vet Immunol Immunopathol 126:9-19.

Chen H, Sohn J, Zhang L, Tian J, Chen S, Bjeldanes LF. 2014. Anti-inflammatory effects of chicanine on murine macrophage

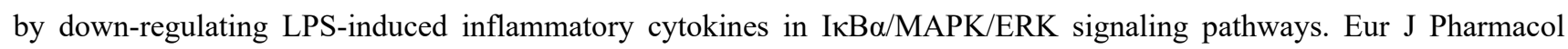
724:168-174.

Cheng A, Wan F, Wang J, Jin Z, Xu X. 2008. Macrophage immunomodulatory activity of polysaccharides isolated from Glycyrrhiza uralensis fish. Int Immunopharmacol 8:43-50.

Dauphinee SM, Karsan A. 2006. Lipopolysaccharide signaling in endothelial cells. Lab Investig 86:9-22.

Dong C, Davis RJ, Flavell RA. 2002. MAP kinases in the immune response. Annu Rev Immunol 20:55-72.

Giansanti F, Rossi P, Massucci MT, Botti D, Antonini G, Valenti P, Seganti L. 2002. Antiviral activity of ovotransferrin discloses an evolutionary strategy for the defensive activities of lactoferrin. Biochem Cell Biol 80:125-130.

Ha YM, Chun SH, Hong ST, Koo YC, Choi HD, Lee KW. 2013. Immune enhancing effect of a Maillard-type lysozymegalactomannan conjugate via signaling pathways. Int J Biol Macromol 60:399-404.

Han EH, Choi JH, Hwang YP, Park HJ, Choi CY, Chung YC, Seo JK, Jeong HG. 2009. Immunostimulatory activity of aqueous extract isolated from Prunella vulgaris. Food Chem Toxicol 47:62-69.

Hong SH, Ku JM, Kim HI, Ahn CW, Park SH, Seo HS, Shin YC, Ko SG. 2017. The immune-enhancing activity of Cervus nippon mantchuricus extract (NGE) in RAW264.7 macrophage cells and immunosuppressed mice. Food Res Int 99:623629.

Ibrahim HR, Hoq MI, Aoki T. 2007. Ovotransferrin possesses SOD-like superoxide anion scavenging activity that is promoted by copper and manganese binding. Int J Biol Macromol 41:631-640.

Jeong JH, Jang S, Jung BJ, Jang KS, Kim BG, Chung DK, Kim H. 2015. Differential immune-stimulatory effects of LTAs from different lactic acid bacteria via MAPK signaling pathway in RAW 264.7 cells. Immunobiology 220:460-466.

Lee JH, Moon SH, Kim HS, Park E, Ahn DU, Paik H-D. 2017. Antioxidant and anticancer effects of functional peptides from ovotransferrin hydrolysates. J Sci Food Agric 97:4857-4864.

Li JW, Liu Y, Li BH, Wang YY, Wang H, Zhou CL. 2016. A polysaccharide purified from Radix Adenophorae promotes cell activation and pro-inflammatory cytokine production in murine RAW264.7 macrophages. Chin J Nat Med 14:370-376.

Li Y, Meng T, Hao N, Tao H, Zou S, Li M, Ming P, Ding H, Dong J, Feng S, Li J, Wang X, Wu J. 2017. Immune regulation mechanism of Astragaloside IV on RAW264.7 cells through activating the NF-kB/MAPK signaling pathway. Int Immunopharmacol 49:38-49.

Lind M, Hayes A, Caprnda M, Petrovic D, Rodrigo L, Kruzliak P, Zulli A. 2017. Inducible nitric oxide synthase: Good or bad? Biomed Pharmacother 93:370-375.

MacMicking J, Xie QW, Nathan C. 1997. Nitric oxide and macrophage function. Annu Rev Immunol 15:323-350. 
Mayer B, Hemmens B. 1997. Biosynthesis and action of nitric oxide in mammalian cells. Trends Biochem Sci 22:477-481.

Moon SH, Lee JH, Lee YJ, Chang KH, Paik JY, Ahn DU, Paik HD. 2013. Screening for cytotoxic activity of ovotransferrin and its enzyme hydrolysates. Poult Sci 92:424-434.

Ninomiya-Tsuji J, Kishimoto K, Hiyama A, Inoue JI, Cao Z, Matsumoto K. 1999. The kinase TAK1 can activate the NIK-I kappaB as well as the MAP kinase cascade in the IL-1 signalling pathway. Nature 398:252-256.

Ren Z, He C, Fan Y, Si H, Wang Y, Shi Z, Zhao X, Zheng Y, Liu Q, Zhang H. 2014. Immune-enhancing activity of polysaccharides from Cyrtomium macrophyllum. Int J Biol Macromol 70:590-595.

Rincon M, Flavell RA, Davis RA. 2000. The JNK and p38 MAP kinase signaling pathways in T cell-mediated immune responses. Free Radic Biol Med 28:1328-1337.

Rizk M, Witte MB, Barbul A. 2004. Nitric oxide and wound healing. World J Surg 28:301-306.

Salvioli S, Capri M, Valensin S, Tieri P, Monti D, Ottaviani E, Franceschi C. 2006. Inflamm-aging, cytokines and aging: State of the art, new hypotheses on the role of mitochondria and new perspectives from systems biology. Curr Pharm Des 12:3161-3171.

Schooltink H, Rose-John S. 2002. Cytokines as therapeutic drugs. J Interferon Cytokine Res 22:505-516.

Seo JY, Lee CW, Choi DJ, Lee J, Lee JY, Park YI. 2015. Ginseng marc-derived low-molecular weight oligosaccharide inhibits the growth of skin melanoma cells via activation RAW264.7 cells. Int Immunopharmacol 29:344-353.

Shen CY, Zhang WL, Jiang JG. 2017. Immune-enhancing activity of polysaccharides from Hibiscus sabdariffa Linn. via MAPK and NF- $\mathrm{KB}$ signaling pathways in RAW264.7 cells. J Funct Foods 34:118-129.

Thieringer R, Fenyk-Melody JE, Le Grand CB, Shelton BA, Detmers PA, Somers EP, Carbin L, Moller DE, Wright SD, Berger J. 2000. Activation of peroxisome proliferator-activated receptor $\gamma$ does not inhibit IL-6 or TNF- $\alpha$ responses of macrophages to lipopolysaccharide in vitro or in vivo. J Immunol 164:1046-1054.

Valenti P, Visca P, Antonini G, Orsi N. 1985. Antifungal activity of ovotransferrin towards genus Candida. Mycopathologia 89:169-175.

Wang ML, Hou YY, Chiu YS, Chen YH. 2013. Immunomodulatory activities of Gelidium amansii gel extracts on murine RAW 264.7 macrophages. J Food Drug Anal 21:397-403.

Wang W, Zou Y, Li Q, Mao R, Shao X, Jin D, Zheng D, Zhao T, Zhu H, Zhang L, Yang L, Wu X. 2016. Immunomodulatory effects of a polysaccharide purified from Lepidium meyenii Walp. on macrophages. Process Biochem 51:542-553.

Wang Z, Xie J, Yang Y, Zhang F, Wang S, Wu T, Shen M, Xie M. 2017. Sulfated Cyclocarya paliurus polysaccharides markedly attenuates inflammation and oxidative damage in lipopolysaccharide-treated macrophage cells and mice. Sci Rep 7:40402.

Wu J, Acero-Lopez A. 2012. Ovotransferrin: Structure, bioactivities, and preparation. Food Res Int 46:480-487.

Yamamura Y, Azuma I. 1983. Immunostimulation in cancer patients. Adv Exp Med Biol 166:1-13.

Yu Y, Shen M, Wang Z, Wang Y, Xie M, Xie J. 2017. Sulfated polysaccharide from Cyclocarya paliurus enhances the immunomodulatory activity of macrophages. Carbohydr Polym 174:669-676.

Zhao T, Feng Y, Li J, Mao R, Zou Y, Feng W, Zheng D, Wang W, Chen Y, Yang L, Wu X. 2014. Schisandra polysaccharide evokes immunomodulatory activity through TLR 4-mediated activation of macrophages. Int J Biol Macromol 65:33-40. 